Article

\title{
Optimization, Transesterification and Analytical Study of Rhus typhina Non-Edible Seed Oil as Biodiesel Production ${ }^{\dagger}$
}

\author{
Inam Ullah Khan, Zhenhua Yan *iD and Jun Chen * \\ Key Laboratory of Advanced Energy Materials Chemistry (Ministry of Education), Renewable Energy \\ Conversion and Storage Centre, College of Chemistry, Nankai University, Tianjin 300071, China; \\ 1120176003@mail.nankai.edu.cn \\ * Correspondence: yzh@nankai.edu.cn (Z.Y.); chenabc@nankai.edu.cn (J.C.) \\ + Dedicated to the 100th Anniversary of Nankai University.
}

Received: 9 October 2019; Accepted: 7 November 2019; Published: 11 November 2019

check for updates

\begin{abstract}
Production of biodiesel from non-edible oils is one of the effective methods to reduce production costs and alleviate the obstacle of traditional raw material supply. Rhus typhina L. (RT) is a promising non-edible plant because it grows fast and has abundant seeds. But previously reported oil content of RT was only $9.7 \%$ and $12 \%$. Further research into improving the biodiesel production of RT seed oil is urgently needed. Here we obtained the biodiesel production of RT with a maximum oil content of $22 \%$ with a low free fatty acid content of $1.0 \%$. The fatty acid methyl ester (FAMEs) of the RT seed oil was produced by a standard optimized protocol use $\mathrm{KOH}$ as a catalyst with the highest yield of $93.4 \%(w / w)$. The quality and purity of RT FAMEs, as well as the physio-chemical characterizations of the biodiesel products, were investigated and compared with the international standard of ASTM D6751 and EN 14214. The values of fuel properties are comparable with mineral diesel and environmentally friendly. Overall, the proposed RT seed oil could be a potential source of raw materials for producing high-quality biodiesel after the optimization and transesterification.
\end{abstract}

Keywords: Rhus typhina biodiesel; non-edible oil; base-catalyzed transesterification; Physico-chemical properties

\section{Introduction}

The speedy reduction of traditional diesel oil resources, as well as the environmental problems epitomized by global warming, has led to a worldwide demand for renewable energy [1]. In response to the crisis, alternative fuels such as biodiesel, bioethanol, biomass, biogas, and synthetic fuels are being developed worldwide [2]. Among them, biodiesel is paid much attention because it is renewable, with reduced emissions of $\mathrm{CO}_{\mathrm{x}}, \mathrm{SO}_{\mathrm{x}}$, and particulate matter into the atmosphere compared to diesel, with a higher flash point, ensuring greater safety in transportation and storage [3]. It is estimated that biodiesel/bioethanol can replace about $10 \%$ of diesel consumption in Europe and $5 \%$ of total fuel demand in Southeast Asia [3,4]. Generally, biodiesel, also named fatty acid methyl ester (FAME), was derived from triglycerides, which are produced from vegetable oils and animal fats with a variety of lipid parameters [5]. Direct use of triglycerides (crude oil) is severely restricted due to its high viscosity and poor ignition quality [4,6]. Therefore, a variety of treatment methods are developed to overcome the viscosity and combustibility of vegetable oils [4]. The strategies including dilution, micro emulsification, pyrolysis, and transesterification for biodiesel fuel production. Among them, the base-catalyzed transesterification reaction can converts triglycerides to methyl ester in shorter reaction times with high efficiency $[4,6,7]$. Therefore, this method has been widely used in the production of biodiesel fuel. 
Currently, $95 \%$ of commercial biodiesel is made through different edible vegetable oil sources such as palm, sunflower, rapeseed, and soybean oil [7,8]. But the industrial expense, especially raw feedstock, is the major obstacle in the moneymaking of edible oil biodiesel [9]. Due to the competition with food raw materials and fuel dispute, the continuous and large-scale production of biodiesel from edible oil is severely challenged [10]. A promising alternative is to shift the focus to the use of non-edible oil resources and/or waste cooking oil to produce biodiesel [11-13]. Many non-edible oil crops have been used for biodiesel production, evaluation, and commercialization such as Jatropha curcas and Karanja [12,14,15], waste tallow [16], Silybum marianum L. [17], wild Brassica Juncea L. [18], and prominently, algae [19]. To further promote it, there is an urgent need to shift the focus to planting non-edible oil plants on poor land, which are often unsuitable for human crops, cost-effective, and have no impact on biodiesel production in the food market [8].

$R$. typhina (sumac staghorn) is one of the non-edible plant's sources, is a member of family Anacardiaceae. Sumac trees are distributed in the subtropical and temperate regions of the world, especially in Africa and North America. It is native to America that can reach a height of 30-35 feet deciduous shrub to a small tree. The $R$. typhina seed has a good economic potential as feedstock for biodiesel. The reasons are as follows: RT plant growth quickly and produces a huge amount of seeds. Three to four hundreds of $R$. typhina trees can be planted per hectare. Approximately one-hectare area will produce $78,000 \mathrm{~kg}$ seeds, the productivity of oil is about 17,160 $\mathrm{kg}$ per hectare. Some studies have been carried out on the extraction of $R$. typhina (RT) seed oil. Ruan et al., 2012 [20] reported that based on acetone/water extract 9:1 v/v, the yield of RT seed oil was 9\% w/w, and Zhang et al., 2018 [21] improved the seed oil content to $12 \%$. However, the studies warrant further research into improving the biodiesel production of RT seed oil.

Here we produced biodiesel from the RT seed oil (RTSO) and optimized their potential for energy production, such as methanol to oil molar ratio, catalyst concentration, reaction temperature, reaction time, and stirring intensity. The techniques including FTIR (Fourier Transform Infra-Red Spectroscopy), NMR $\left({ }^{1} \mathrm{H}\right.$ and ${ }^{13} \mathrm{C}$ ) (Nuclear Magnetic Resonance Spectroscopy), GC-MS (Gas Chromatography and Mass Spectroscopy) were used to confirm the ester conversion and fatty acid composition. The physic-chemical properties of the FAME were investigated and compared with petrodiesel and standards of ASTM D6751 and EN14214 i.e., density, kinematic viscosity, cloud point, pour point, flash point, fire point, Cetane number, oxidation stability, saponification value, iodine value, acid value, specific gravity, ash content, and cold filter plugging point. Elements analysis by inductively coupled plasma atomic emission spectroscopy (ICP-OES) and elemental analyzer (EA) show that biodiesel is environmentally friendly. Overall, a prospective inedible raw material for biodiesel making was discovered and scrutinized.

\section{Materials and Methods}

\subsection{Source Collection and Preparation of Seeds for Oil Extraction}

The R. typhina seeds were collected from the wild/wasteland in Tianjin Binhai New Area, China. The seeds were separated by hand, washed with distilled water, and then dried in the sunlight first for $48 \mathrm{~h}$ and then at $60^{\circ} \mathrm{C}$ oven-dried (to remove the moisture) until the seeds reached an unchanged weight. A grinder (XIANTAOPAI XTP-10000A, Zhejiang, China) was used to grind the seeds. The ground seeds were oven-dried at $60^{\circ} \mathrm{C}$ for $1 \mathrm{~h}$ and $30 \mathrm{~min}$ to finish the moisture and then extracted to obtain the oil. Photographs of plants and seeds processing are shown in Figures S1 and S2 (Supplementary Materials).

\subsection{Oil Extraction}

R. typhina seeds were shelled, dried, and pulverized with a grinder (Xiantaopai XTP-10000A, Zhejiang, China). The oil was extracted using soxhlet [22] and mechanical oil extractor (Fangtai Shibayoufang FL-S2017 China and Fangtai Shibayoufang J508, Guangdong, China) (Table S1, 
Supplementary Materials). The oil extraction was occurring in a soxhlet instrument at $90^{\circ} \mathrm{C}$ for $7 \mathrm{~h}$ by various kinds of solvent were used, including petroleum ether, acetone, dichloromethane, and ethyl acetate. The particles and impurities were removed by filter paper (pore size 30-50 $\mu \mathrm{m}$ ), and the crude RT oil was recovered at $80^{\circ} \mathrm{C}$ under reduced pressure by using a rotary evaporator (Tokyo Rikakikai Co. Ltd. N-1210B, Tokyo Japan). The obtained RT oil was stored and dried over anhydrous sodium sulfate before use.

\subsection{Biodiesel Production Procedure}

By applying $50 \mathrm{~g}$ of RT crude oil, $10 \mathrm{~mL}$ of methanol at molar ratio $5: 1$, and $2.3 w / w \%$ of $\mathrm{KOH}$ catalyst, the RT seed oil biodiesel was prepared. The transesterification reaction is shown in Figure 1. At $65^{\circ} \mathrm{C}$ for $1 \mathrm{~h}$ under reflux, the reaction was carried out, and $600 \mathrm{rpm}$ was the agitation rate [23]. By using $99.99 \%$ excess of methanol [24], the process was performed, such as methanol to oil ratio was 5:1, $\mathrm{KOH}$ ratio was $2.9 w / w \%$. The reflux condenser was furnished with a reactor to cool down the methanol as it comes out from the reaction process mixture. The reaction mixture was then put in a separating funnel and keep for a one-night stay that the biodiesel, soap, and glycerol can become separate from each other by layers making, the bottom phase is glycerol, and the upper phase is biodiesel. After reaction completion, crude glycerine can separate through gravity, and $\mathrm{KOH}$ can be detached with 3-4 time washing with hot distilled water. The complete removal of the catalyst can be check through a phenolphthalein indicator. The leftover unreacted methanol and moisture were finished through vacuum distillation and continue the process till when it confirms that there is no unreacted methanol and moisture in the final product, and the FAMEs weight loss is constant. The crude FAMEs were further washed 3-4 times with heated deionized water, centrifuging and dry with a vacuum dryer to confirm its purity. The phase separation was usually starting very quickly and can be observed in start $10 \mathrm{~min}$, but the biodiesel phase was cloudy, it shows incomplete detachment. The result shows that the cloudy biodiesel layers can become clean and clear, giving them enough time for settling, and complete impartiality needs up to $20 \mathrm{~h}$. In fact, during the resolution process, the transesterification process was still in progress. Hence, to give them a long time for separation is more beneficial, the separation and conversion yields. All analytical reagent grade chemicals were used.<smiles>[R]C(=O)OC([2H])C(OC([R])=O)C([CH])OC([R])=O</smiles>

Triglyceride

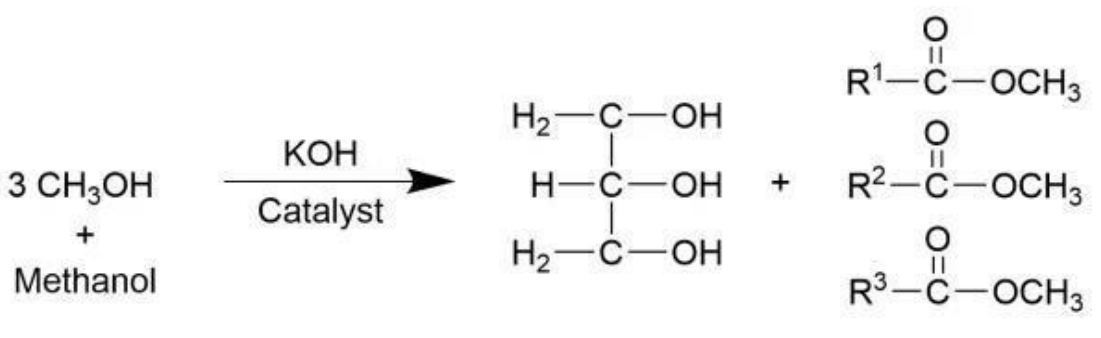

Glycerol
Biodiesel

Figure 1. Transesterification reaction.

\subsection{FTIR Study}

The Fourier Transform Infrared (FT-IR) bands spectroscopy were verified by a (Bruker Vertex 70 FT-IR spectrometer, Germany) with a resolution of $1 \mathrm{~cm}^{-1}$, scanning 15 times, and using Nujol mull as a dispersive medium in the range of $400-4000 \mathrm{~cm}^{-1}$, to originate the obtained biodiesel describe through various functional groups characterization.

\subsection{NMR Study}

The RT FAMEs NMR spectrum was obtained by (Bruker Avance Ш400 NMR Spectrometer, Karlsruhe, Germany) at $400 \mathrm{MHz}\left({ }^{1} \mathrm{H}-\mathrm{NMR}\right)$ or $100 \mathrm{MHz}\left({ }^{13} \mathrm{C}-\mathrm{NMR}\right)$. Deuterated chloroform was used as a solvent, and tetramethylsilane was used as the internal standard. The RT biodiesel ${ }^{1} \mathrm{H}$ NMR 
(300 MHz) spectrum was documented with a cycle delay of $1.0 \mathrm{~s}$, and several scans of 8 times, with a pulse duration of $30^{\circ}$. A carbon ${ }^{13} \mathrm{C}$ NMR $(75 \mathrm{MHz})$ spectrum was recorded with a pulse duration of $30^{\circ}$ and a cycle delay of $1.89 \mathrm{~s}$, and a scan of 160 times [25,26].

\subsection{GCMS Study}

The obtained RT FAMEs result was checked and tested by GCMS (QP2010SE, Shimadzu, Tokyo, Japan). GC-MS conditions are listed in Table 1. Detail procedure is present in Figure S2 (Supplementary Materials).

Table 1. Gas chromatograph conditions.

\begin{tabular}{|c|c|}
\hline Parameter. & Descriptions \\
\hline \multirow{5}{*}{ Column } & QP2010SE, Shimadzu \\
\hline & PEG-20M \\
\hline & Length: $30 \mathrm{~m}$ \\
\hline & Internal diameter: $0.32 \mathrm{~mm}$ \\
\hline & Film thickness: 1 um \\
\hline Injector temperature & $220^{\circ} \mathrm{C}$ \\
\hline Detector temperature (EI 250) & $210^{\circ} \mathrm{C}$ \\
\hline Carrier gas & Helium, flow rate $=1.2 \mathrm{~mL} \mathrm{~min}^{-1}$ \\
\hline Injection & $\mathrm{V}=1 \mathrm{uL}$ \\
\hline Split & Flow rate $=40: 1$ \\
\hline \multirow{3}{*}{ Temperature program } & Initial temperature $=100^{\circ} \mathrm{C}$ \\
\hline & Rate of progression $=10^{\circ} \mathrm{C} \mathrm{min}^{-1}$. \\
\hline & Final temperature $=210^{\circ} \mathrm{C}, 20 \mathrm{~min}$. \\
\hline
\end{tabular}

\subsection{ICP-OES and EA Study of RT Biodiesel for Elemental Analysis}

The presence of metals in the RTSO FAMEs was studied using Inductively Coupled Plasma Spectrometer (Spectro-blue, Kleve, Germany) and Elemental Analyser (Vario EL CUBE, Hanau, Germany). The procedure is presented in Figure S3 (Supplementary Materials).

\section{Results and Discussion}

Rhus typhina plants and their pre-treated seeds are shown in Figure 2. Several varieties of solvent were used to extract oil from the RT seed powder, including petroleum ether, acetone, dichloromethane, and ethyl acetate. Seed collection at the right time, proper pre-treatment of seeds (put in sunlight first for $48 \mathrm{~h}$ and then at $60{ }^{\circ} \mathrm{C}$ oven-dried for $1.5 \mathrm{~h}$ to remove the moisture), use of petroleum ether as the extraction solvent and environmental conditions have a significant role in obtaining the high oil contents. The results are summarised in Table 2. Since the lower percentage of FFAs in the oil is the significant point to process direct transesterification of RT seed oil, this data indicates that petroleum ether is the best solvent for extracting oil from RT seeds because it provides high yields of oil and less FFAs. Besides, petroleum ether is less expensive than other solvents and can be recycled from the process. The oil and FFAs content were related to the polarity of the solvent extracted, in the order of petroleum ether $<$ ethyl acetate $<$ acetone $<$ dichloromethane. Less polar solvents can extract larger amounts of non-polar oils (triglycerides) and less amount highly polar FAA. By soxhlet extraction [22], petroleum ether gives the highest extracted oil content of $22 \mathrm{wt}$. \% (FFAs $=1.0 \mathrm{wt} . \%$ ), which is significantly higher than the reported seed oil contents (Ruan et al. [20] reported that based on acetone/water extract 9:1 v/v, the yield of RT seed oil was 9.7\% w/w, ZHANG et al. [21] reported that based on AOAC method the seed oil content was $12 w / w \%)$. Ethyl acetate gives low oil content of $17.8 \mathrm{wt}$. \% (FFAs $=1.3 \mathrm{wt}$. \%), while more polar solvents like acetone and dichloromethane give somewhat lower oil content of 16-14.2 wt. \% (FFAs $=1.5-1.8 \mathrm{wt}$. \%). Based on these extraction results using petroleum ether and the ability to produce RT seeds oil, the RT seed could be an efficient source for biodiesel production as an alternative energy. 


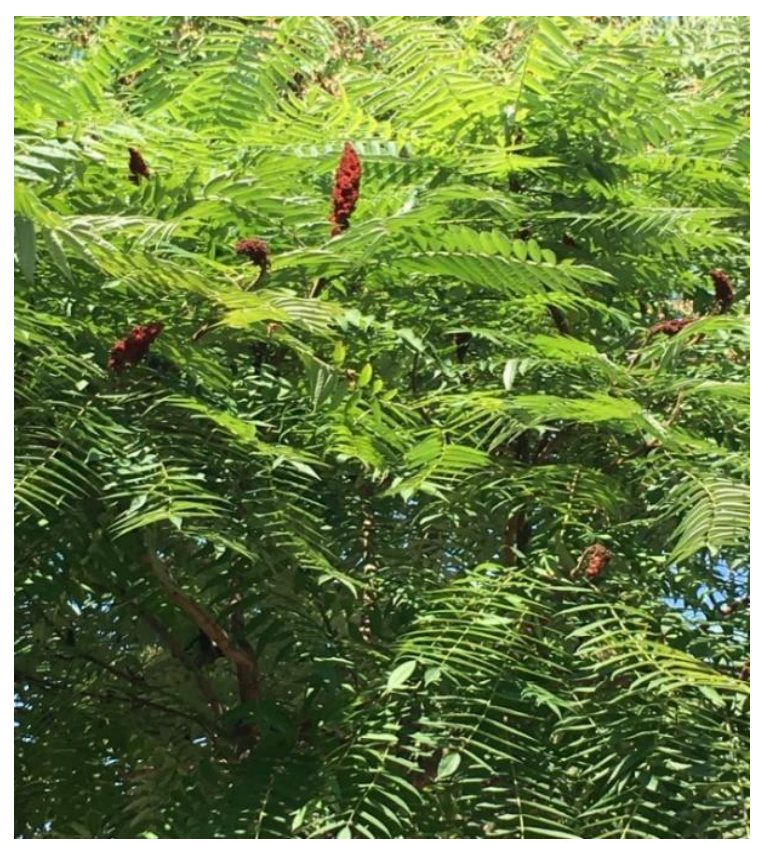

(a)

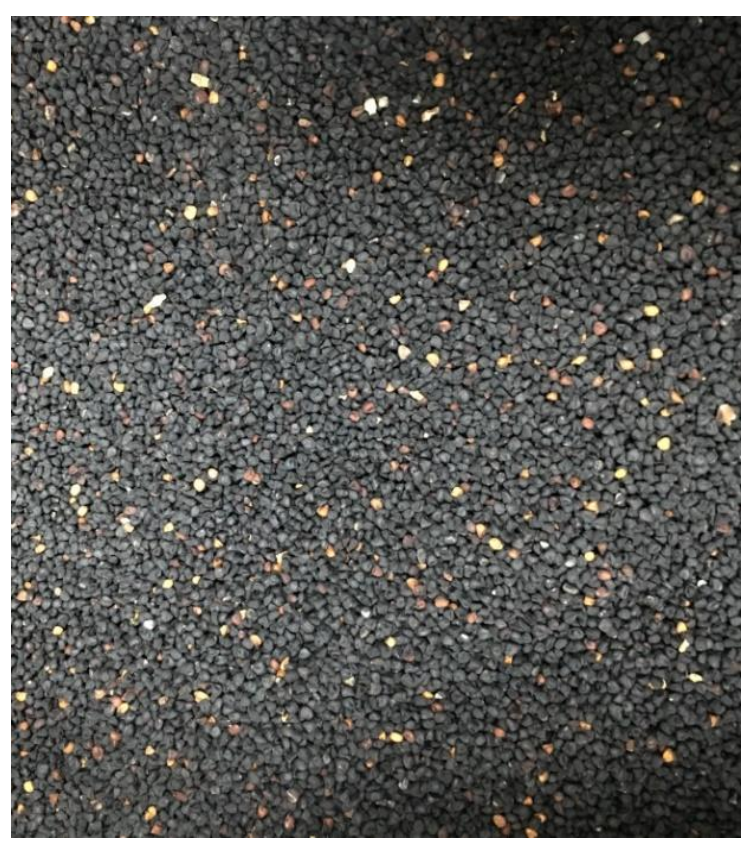

(b)

Figure 2. (a) Optical photographs of RT mature plant and (b) pre-treated seeds.

Table 2. FFAs and oil contents of extracted RT seed oil.

\begin{tabular}{ccc}
\hline Solvent & FFAs Content (wt. \%) & Oil Content (wt. \%) \\
\hline Petroleum ether & 1.0 & 22 \\
Acetone & 1.5 & 16 \\
Dichloromethane & 1.8 & 14.2 \\
Ethyl acetate & 1.3 & 17.8 \\
\hline
\end{tabular}

\subsection{Optimizations of Reaction Variables on Conversion Yield}

We have studied five different parameters through which we have applied different conditions, and each parameter was tested in three conditions to check that what is the most proper and suitable condition for obtaining the optimum result. The five parameters are as follow and discuss one by one, including methanol/oil ratio, catalyst concentration, temperature, stirring intensity, and time. The detail experimental results were presented in Table S2.

\subsubsection{Effect of Methanol to Oil Molar Ratio on Yield}

Methanol to oil molar ratio is one of the main factors affecting the ester conversion during the transesterification process. The transesterification of RT oil was evaluated and investigated at different methanol to oil range. The added amount of methanol in the reaction was varied from 4:1, 5:1, 6:1, and 7:1 (as shown in Figure 3). While temperature $\left(65^{\circ} \mathrm{C}\right)$, stirring intensity $(700 \mathrm{rpm})$, and reaction time (60 $\mathrm{min}$ ) was kept constant. The best proportion of methanol and oil was $6: 1$, in which the conversion yield was $91.66 \%$. But at proportion $7: 1$, the conversion percentage was as low as to $70 \%$. It was observed that when the proportion of methanol to oil rises from 4:1-6:1, the product yield was increased. Whereas in an additional increasing proportion of methanol to oil, a reduction in biodiesel production was observed. Excessive methanol can make it difficult to separate glycerol from the biodiesel phase. The higher methanol ratio restricts the separation of glycerol due to high solubility. Thus, in the presence of residual glycerol in the biodiesel layer allows the equilibrium reaction to start the backward reaction and again met with the methyl ester to form a monoglyceride [27]. The results show that excessive use of methanol has no substantial effect on biodiesel production; in fact, the 
separation of ester and glycerol is complicated. Therefore, a molar ratio of $6: 1$ is the optimum ratio of RT methyl ester yield.

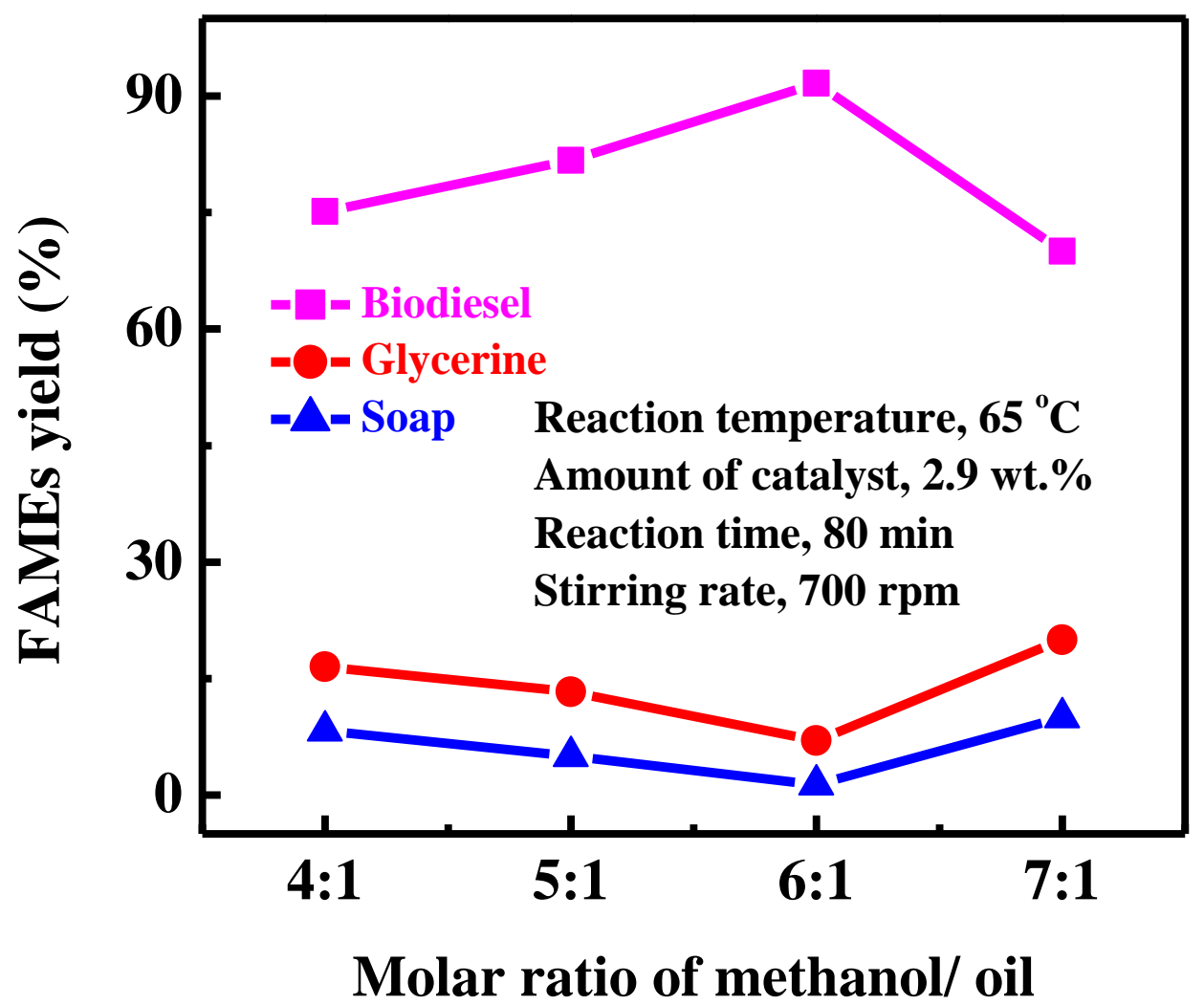

Figure 3. The effect of methanol to oil molar ratio on RTOB yield.

\subsubsection{Effect of Reaction Temperature on FAMEs Yield}

Temperature is a very important factor in the optimization process and has a great impact on product yield. In this work, constant parameters such as $\mathrm{KOH}$ concentration $(2.9 \mathrm{wt}$. \%), methanol to oil proportion (6:1) reaction time (60 $\mathrm{min})$, and stirring speed $(700 \mathrm{rpm})$ were used. A graph of biodiesel conversion (\%) versus temperatures such as 60,65 , and $70{ }^{\circ} \mathrm{C}$ is shown in Figure 4 . The product yield was increased from $60^{\circ} \mathrm{C}$ to $65^{\circ} \mathrm{C}$; it is clear from the reaction process that the temperature had a progressive effect on the transesterification of the RT oil to biodiesel. Though, when the reaction temperature raised from $65^{\circ} \mathrm{C}$ to $70^{\circ} \mathrm{C}$, we noticed a slight decrease in the reaction yield, which possibly due to the accelerated saponification reaction at a high temperature. When the transesterification reaction temperature is higher than the boiling point of the alcohol, the methanol cannot evaporate, and a huge number of the bubble will produce, which make fast the reaction and increase the saponification of glycerides [28]. Therefore, $65^{\circ} \mathrm{C}$ is the optimum temperature for the reaction. 


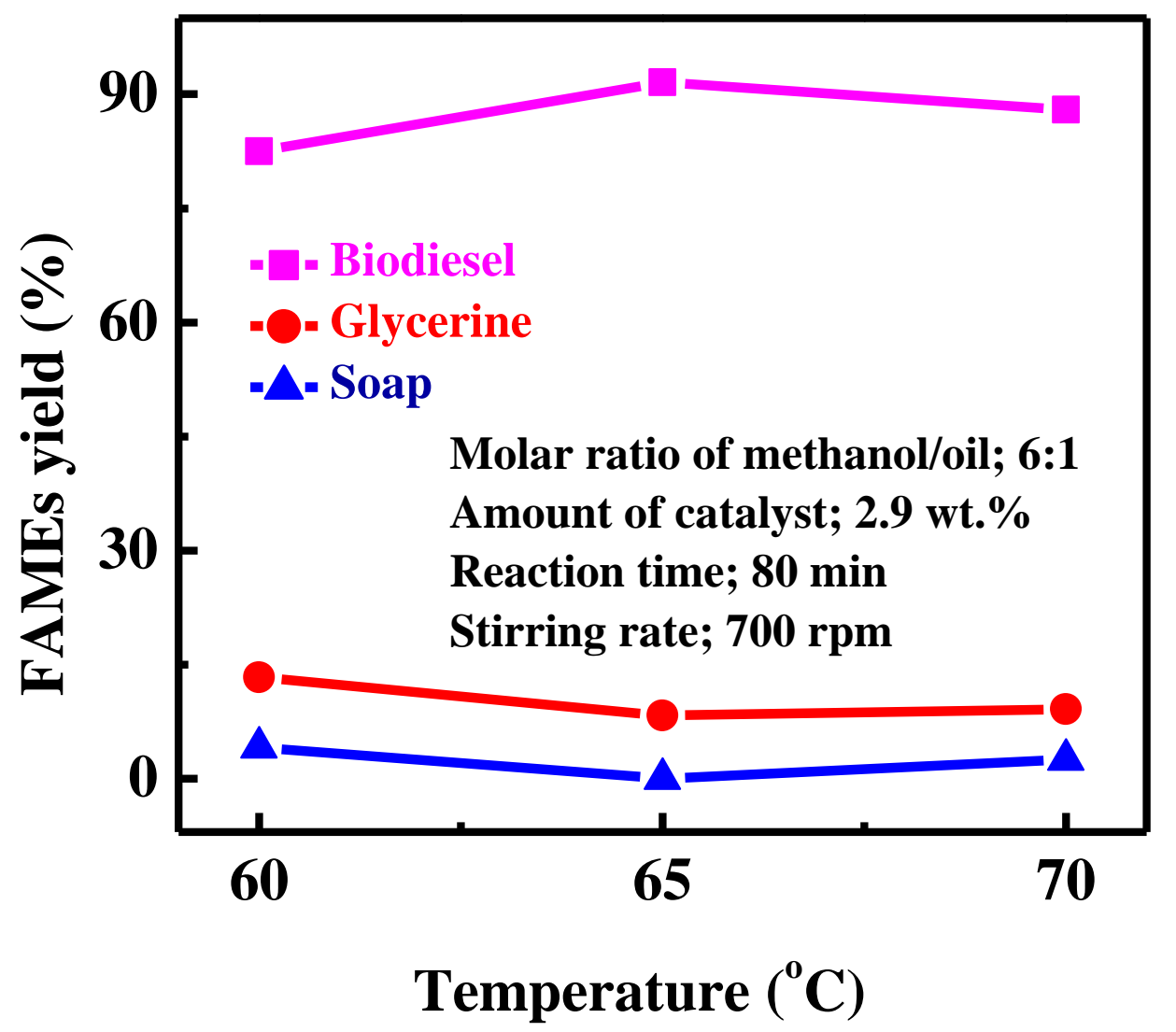

Figure 4. Effect of temperature on RTOB yield.

\subsubsection{Effect of the Catalyst Concentration on FAMEs Yield}

The process of variables that can affect transesterification, in addition to saponification and hydrolysis are catalyst concentration. In this reaction, methanol to oil molar ratio (6:1), temperature $\left(65^{\circ} \mathrm{C}\right)$, reaction time $(60 \mathrm{~min})$, stirring intensity $(700 \mathrm{rpm})$ was kept constant, respectively. The catalyst $(\mathrm{KOH})$ range of 2.0, 2.4, 2.9, and $3.8 \mathrm{wt}$. \% has applied for the methanol decomposition in the RT seed oil. Figure 5 demonstrates the production of FAMEs at various $\mathrm{KOH}$ range. A small amount of catalyst 2.0 and $2.4 \mathrm{wt}$. \% was not enough for the completion of the reaction. The highest conversion percentage rate was achieved $(91.66 \%)$ at $2.9 \mathrm{wt}$. \% of the catalyst. An additional increase in the catalyst concentration will negatively affect the conversion ratio. When the $\mathrm{KOH}$ amount was increased from 2.9 to $3.8 w / w \%$, the production of the methyl ester decreases, resulting in an increase in the viscosity of the reactants, and a decrease in the yield, a large amount of soap was observed. This observation has been explained by an increase in saponification due to the excess of the basic catalyst rather than the esterification of the triglyceride [29]. By increasing the saponification process reaction, the extra amount of catalyst will improve and help in soap formation so that the FAMEs solubility chances will increase in the glycerol, FAMEs, and glycerol mixture will appear [30]. 


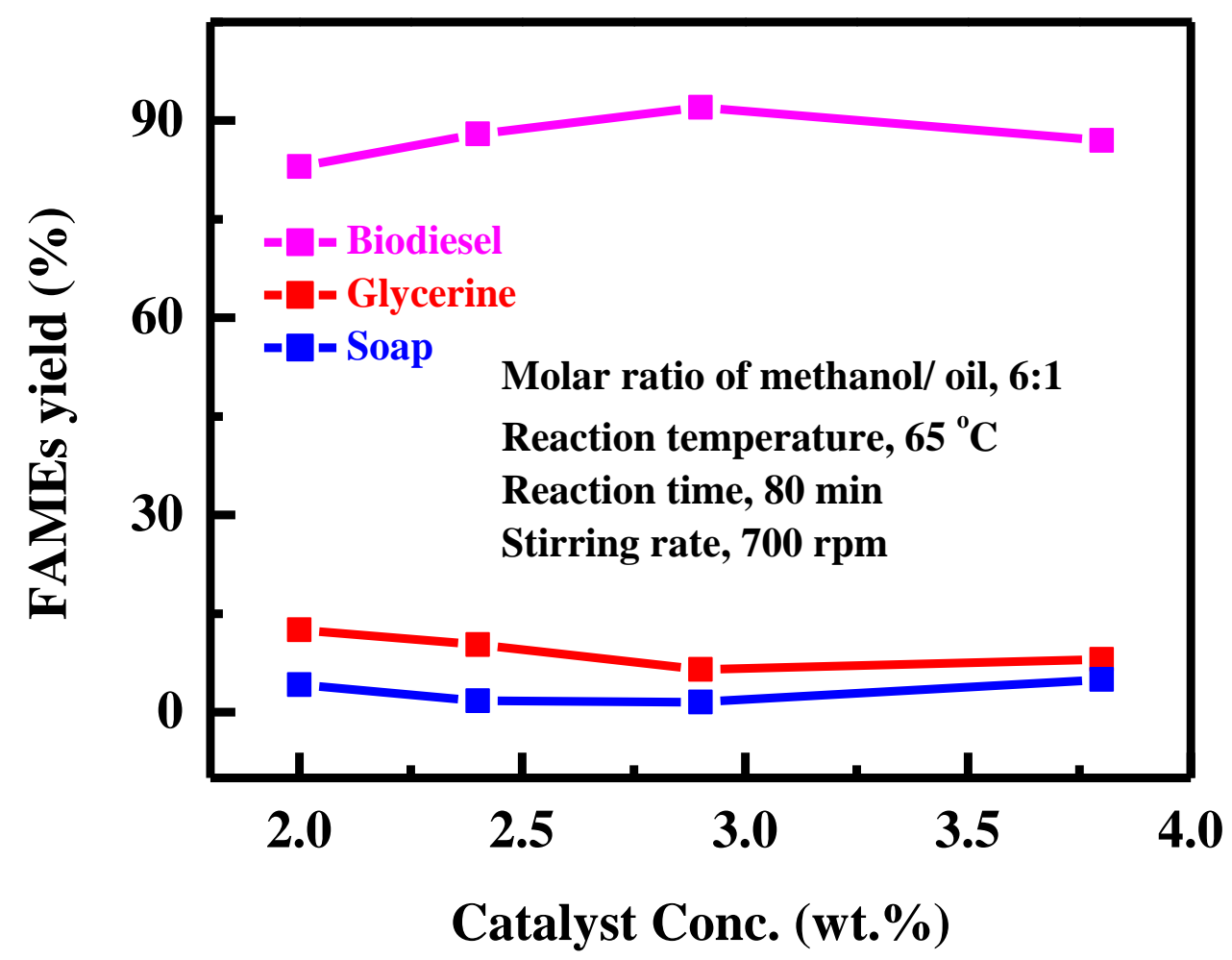

Figure 5. The effect of catalyst concentration on RTOB yield.

\subsubsection{Effect of Agitation Speed on FAMEs Yield}

Stirring is a key factor in the optimizations because it affects biodiesel production in both ways. In the $\mathrm{KOH}$ and methanol mixture, the fat and oil are not soluble, so in the transesterification process, the mixing is very important. The decomposition of methanol was carried out at various agitation speeds, i.e., 500, 600, 700, and $800 \mathrm{rpm}$. While the methanol to oil molar ratio (6:1), $\mathrm{KOH}$ concentration ( $2.9 \mathrm{wt} . \%)$, reaction temperature $\left(65^{\circ} \mathrm{C}\right)$, and reaction time $(60 \mathrm{~min})$ was kept constant. The FAMEs production at diverse mixing speed is shown in Figure 6. The reaction was witnessed to be incomplete at $500 \mathrm{rpm}$, and the mixing rate was not significant for methanol decomposition. The yields of the methyl esters at 600 and $700 \mathrm{rpm}$ were $90 \%$ and $92.5 \%$, respectively. As clarified by the results, a direct correlation was elucidated between the agitation rate and the RTOME yield, i.e., as the agitation rate increased, an increase in yield was observed. Therefore, a mixing rate of $700 \mathrm{rpm}$ provides the best conversion rate (92.5\%) of RT oil to RTOME. This is consistent with the previous studies [31-33], which concluded that increasing the agitation rate promotes the homogenization of the reactants, resulting in higher methyl ester yields. Once the two phases are mixed, and the reaction is started, stirring is no longer needed. It is clear from the results that a further stirring rate $(800 \mathrm{rpm})$ has no significant effect on RTOMEs yield, but the result was the same as $700 \mathrm{rpm}(95.5 \%)$. 


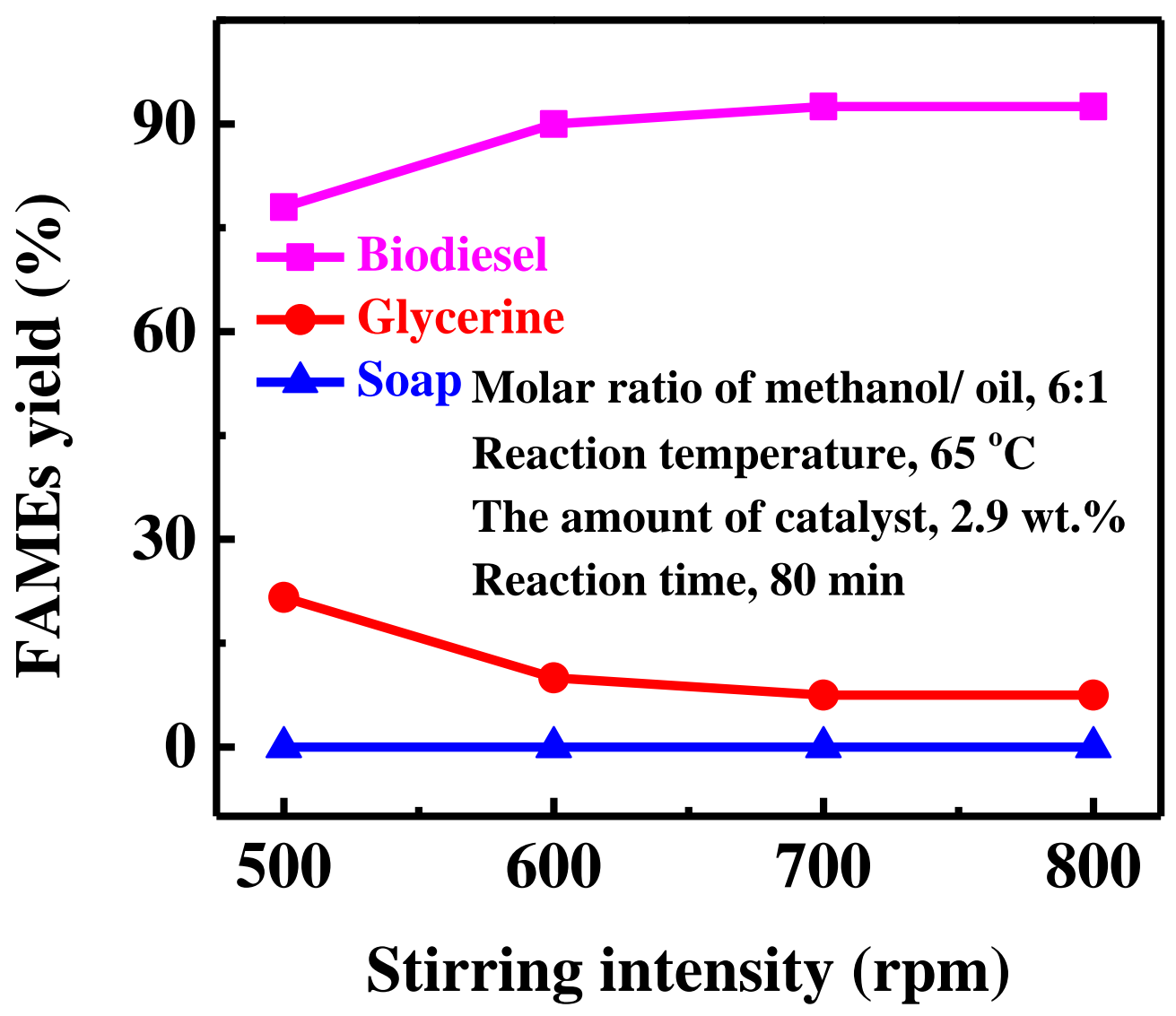

Figure 6. The effect of stirring intensity on RTOB yield.

\subsubsection{Influence of Reaction Time on FAMEs Yield}

The methyl ester transformation percentage rises with the reaction time. Also, the influence of reaction time on methyl ester alteration is shown in Figure 7 . The influence of biodiesel yield was studied at different time rates of 40,60, 80, and $100 \mathrm{~min}$. Though methanol to oil molar ratio (6:1), reaction temperature $\left(65^{\circ} \mathrm{C}\right)$, catalyst concentration $(2.9 \mathrm{wt} . \%)$, and stirring intensity $(700 \mathrm{rpm})$ was kept constant. The current results presented that biodiesel conversion reached at the optimum rate in 80 $\mathrm{min}$. Experimental results show that biodiesel production increase as the reaction time increases. The reaction time has no significant effect after $80 \mathrm{~min}$, and the methyl ester production starts decreasing, it is indicating that the FAMEs reached the distribution equilibrium. As the duration increases, further, the reaction process will begin to react backward, and the ester yield will certainly begin to decrease by $88 \%$ at $100 \mathrm{~min}$. This is consistent with the literature data showing that longer reaction times will result in lower yields due to the reverse reaction of transesterification (hydrolysis), which tends to produce more fatty acid to forming soaps [34,35]. According to the experimental results, the reaction time has an important role in the increase and decrease of biodiesel conversion. The minimum yield was obtained at $40 \mathrm{~min}$, and the optimum yield occurred at $80 \mathrm{~min}$. 


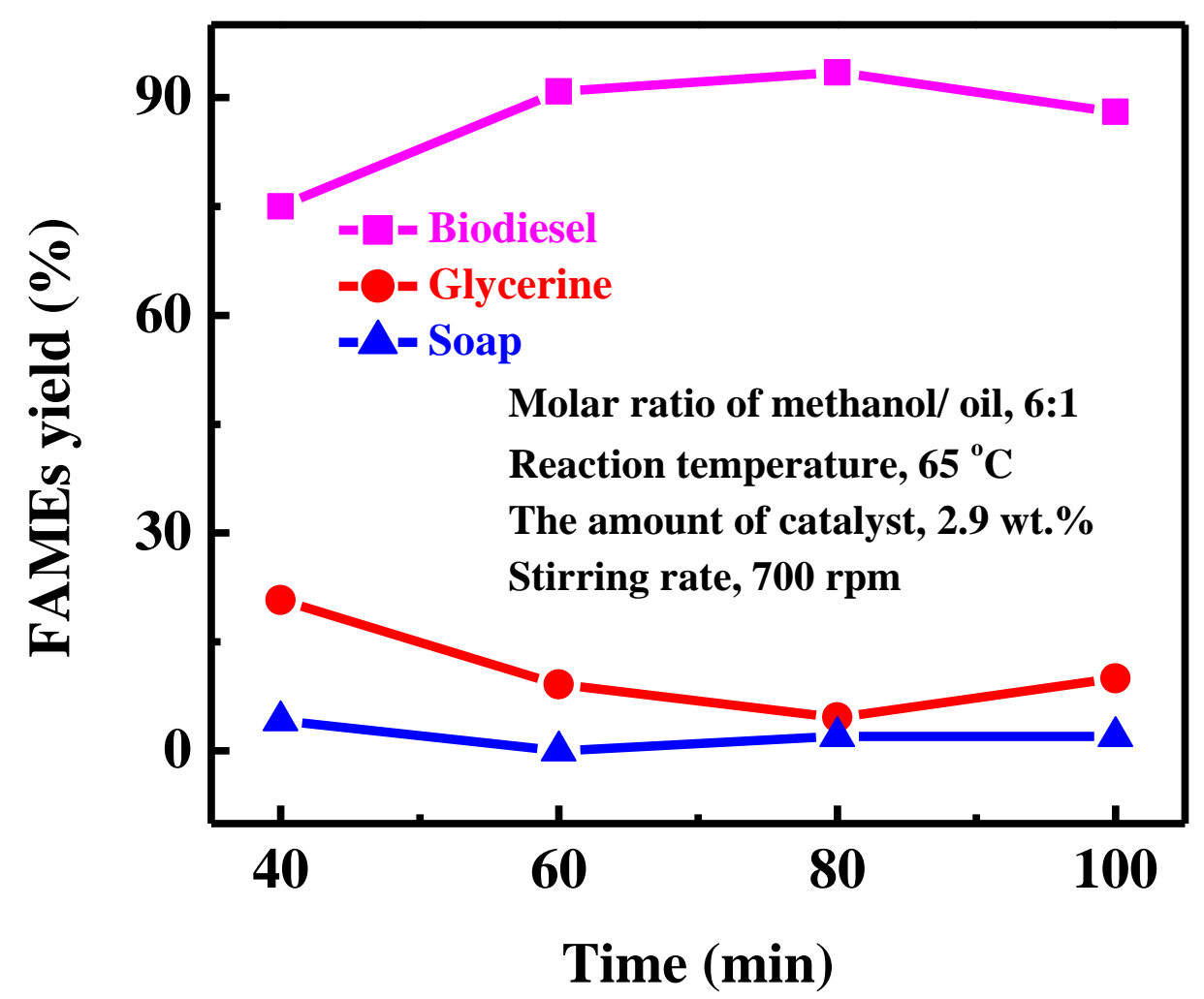

Figure 7. The effect of reaction time on RTOB yield.

\subsection{Physio-Chemical Characterization of R. typhina Methyl Ester}

The physicochemical properties of the Rhus typhina seed oil biodiesel (RTSOBD) were evaluated and examined according to ASTM and EN standards and matched well except kinematic viscosity. The kinematic viscosity $\left(6.3 \mathrm{~mm}^{2} / \mathrm{s}\right)$ is slightly higher than ASTM D6751 $\left(1.9-6.0 \mathrm{~mm}^{2} / \mathrm{s}\right)$. Kinematic viscosity needs further modification to improve its value under the limits. Accordingly, the kinematic viscosity of the BD produced from the RT seed oil is slightly high than those of conventional biodiesels, and thus must be blended with other less viscosities diesel fuels (biodiesels or petrodiesel fuel) to lessen its properties to the acceptable limits. Also, the results obtained were matched with reported data from the same source of biodiesel mentioned by other researchers and compared with petrodiesel. The results are shown in Table 3. 
Table 3. Physiochemical characterizations of $R$. typhina seed oil biodiesel.

\begin{tabular}{|c|c|c|c|c|c|c|}
\hline Studied Parameters & EN 14214 & ASTM D6751 & Petro-Diesel & RT Experimental Result & ZHANG et al., 2018 [21] & Ruan et al., 2012 [20] \\
\hline Oil content $\%$ & - & - & - & $20-22 \%$ & $12 \%$ & $9.7 \%$ \\
\hline Density @ $15^{\circ} \mathrm{C}\left(\mathrm{g} / \mathrm{cm}^{3}\right)$ & $0.86-0.90$ & $0.86-0.90$ & $0.81-0.87$ & 0.879 & 0.879 & - \\
\hline $\begin{array}{c}\text { Kinematic viscosity @ } 40^{\circ} \mathrm{C} \\
\left(\mathrm{mm}^{2} / \mathrm{S}\right)\end{array}$ & $3.5-5.0$ & $1.9-6.0$ & $1.3-4.1$ & 6.3 & 6.87 & - \\
\hline Flash point, $\left({ }^{\circ} \mathrm{C}\right)$ & Min 120.0 & Min 130 & $\geq 52$ & 168 & 165 & - \\
\hline Free fatty acid $(\%)$ & Max 0.50 & $<1$ & - & 1.0 & - & - \\
\hline $\begin{array}{l}\text { Saponification value (mg } \\
\mathrm{KOH} / \mathrm{g})\end{array}$ & - & - & - & 175.6 & - & - \\
\hline Iodine value ( $\left.\mathrm{g} \mathrm{I}_{2} / 100 \mathrm{mg}\right)$ & Max. 120 & Max. 120 & - & 85 & - & - \\
\hline Cloud point $\left({ }^{\circ} \mathrm{C}\right)$ & - & - & $-15-5$ & 7 & - & - \\
\hline Pour point $\left({ }^{\circ} \mathrm{C}\right)$ & - & - & -2.0 & -11 & - & - \\
\hline Fire point $\left({ }^{\circ} \mathrm{C}\right)$ & - & - & - & 198 & - & - \\
\hline Oxidation stability $\left(110^{\circ} \mathrm{C}, \mathrm{h}\right)$ & Min 6 & Min. 3 & 25.8 & 18.3 & - & - \\
\hline Ash content $(\mathrm{g} / 100 \mathrm{~g})$ & - & - & - & 0.3 & - & - \\
\hline Specific gravity & - & - & - & 0.855 & - & - \\
\hline $\begin{array}{l}\text { Cold filter plugging point } \\
\left(\mathrm{CFPP},{ }^{\circ} \mathrm{C}\right)\end{array}$ & Max.19 & Max.19 & -16 & 14 & - & - \\
\hline Sulphur content $(w / w \%)$ & $<0.01$ & $<0.01$ & - & 0.01 & - & - \\
\hline Phosphorous content $(\mathrm{mg} / \mathrm{kg})$ & $<10$ & $<10$ & - & 4 & - & - \\
\hline Carbon residue $(w / w \%)$ & - & - & - & 0.19 & - & - \\
\hline
\end{tabular}




\subsection{NMR Spectroscopy}

\subsection{1. ${ }^{1} \mathrm{H}$ NMR Analysis}

The biodiesel yield during the transesterification process was determined by using ${ }^{1} \mathrm{H}$ NMR techniques, and the progression of its characteristic spectra was depicted. When ${ }^{1} \mathrm{H}$ NMR was used, the produce methyl ester was used to monitor the product by the protons of the methylene group adjacent to the ester moiety in the TAG and the protons of the alcohol moiety. Though by ${ }^{1} \mathrm{H}$ NMR spectroscopy technique, the RT seed oil biodiesel was characterized, the spectra of which are shown in Figure 8 and Table S3 (Supplementary Materials). The distinguishing proton methyl ester peaks were detected to be a singlet at 3.663 and triplet of the $\alpha-\mathrm{CH}_{2}$ proton at $2.308 \mathrm{ppm}$ correspondingly. The existence of methyl ester in biodiesel was approved by these two distinctive peaks. At $0.895 \mathrm{ppm}$, the peaks were detected to be terminal methyl proton; at $1.319 \mathrm{ppm}$, the associated methylene protons of the carbon chain were detected, which shows a strong confirmation. A strong signal was detected for the $\beta$-carbonyl methylene proton at $1.623 \mathrm{ppm}$ and olefin hydrogen at $5.342 \mathrm{ppm}$, respectively. According to the literature review, several studies specified that this diverse standardization curve established on ${ }^{1} \mathrm{H}$ NMR spectroscopy was used to enumerate the reaction yield throughout biodiesel production by transesterification of a mixture of methanol and fatty acids [36-39]. In this regard, the ${ }^{1} \mathrm{H}$ NMR spectrum of RT oil biodiesel can be used to quantify the conversion of triglycerides to methyl esters during transesterification, as evidenced by previous studies [40,41]. In this study of ${ }^{1} \mathrm{H}$ NMR spectra, the divers and distinctive analyses were existing in the Rhus typhina seed oil biodiesel methyl ester spectrum. The appropriate indications selected for incorporation are the methoxy group of the methyl ester at $3.66 \mathrm{ppm}$ and the methyl ester group of the $\alpha$-carbonyl methylene proton at $2.308 \mathrm{ppm}$. Thus, ${ }^{1} \mathrm{H}$ NMR spectroscopy showed a strong conversion of TAG to Rhus typhina methyl ester.

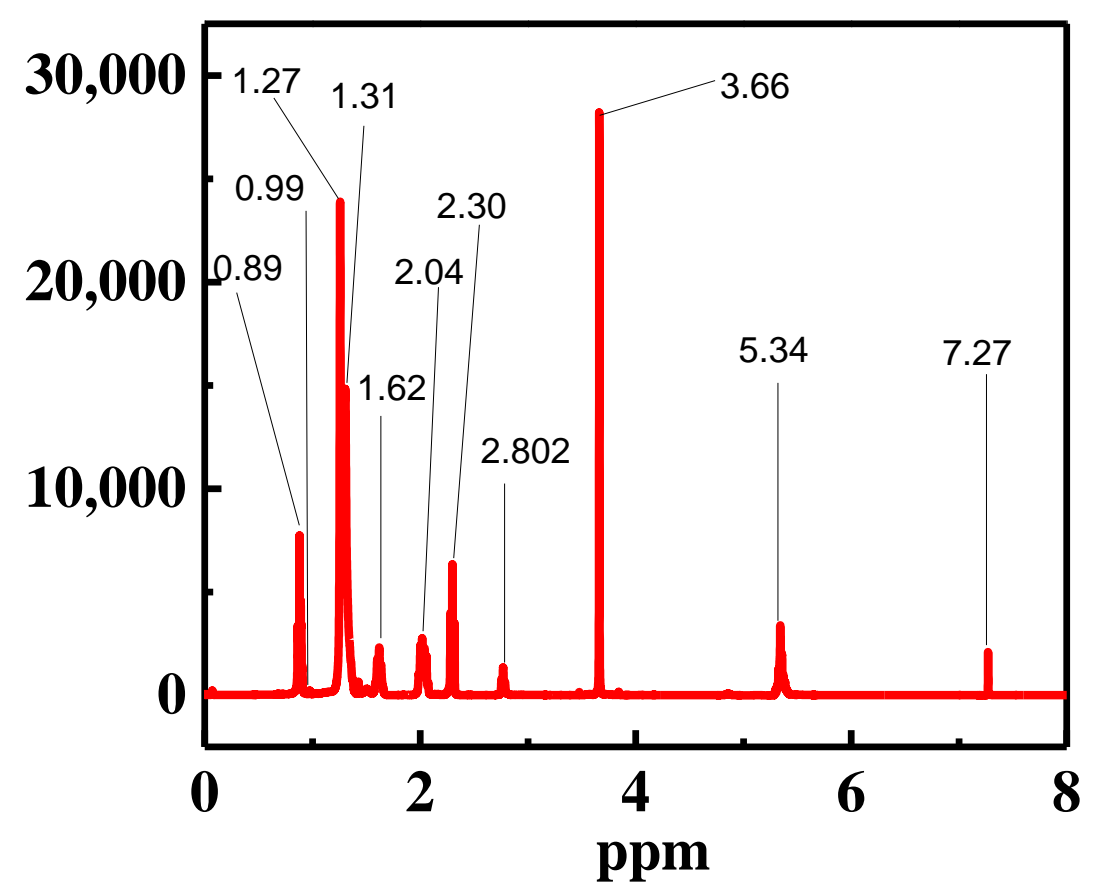

Figure 8. ${ }^{1} \mathrm{H}$ NMR spectrum shows RT FAMEs.

\subsection{2. ${ }^{13} \mathrm{C}$ NMR Analysis}

Ester carbonyl important peaks (-COO-) 174.24 and (C-O) 51.32 ppm associated with RT biodiesel were depicted by using ${ }^{13} \mathrm{C}$ NMR spectroscopy. The Rhus typhina biodiesel ${ }^{13} \mathrm{C}$ NMR spectra are shown in Figure 9, Table S4 (Supplementary Materials). The unsaturated methyl ester peaks were detected at 130.21 and $127.89 \mathrm{ppm}$, respectively. The other associated peaks at $14.1 \mathrm{ppm}$ and 22.5-34.1 ppm, 
correspondingly represent the terminal carbon of the methyl group and the methylene carbon of the long-chain fatty acid ester. The present experimental work spectra were closely matched with the literature work [42] and thus approve our verdicts.

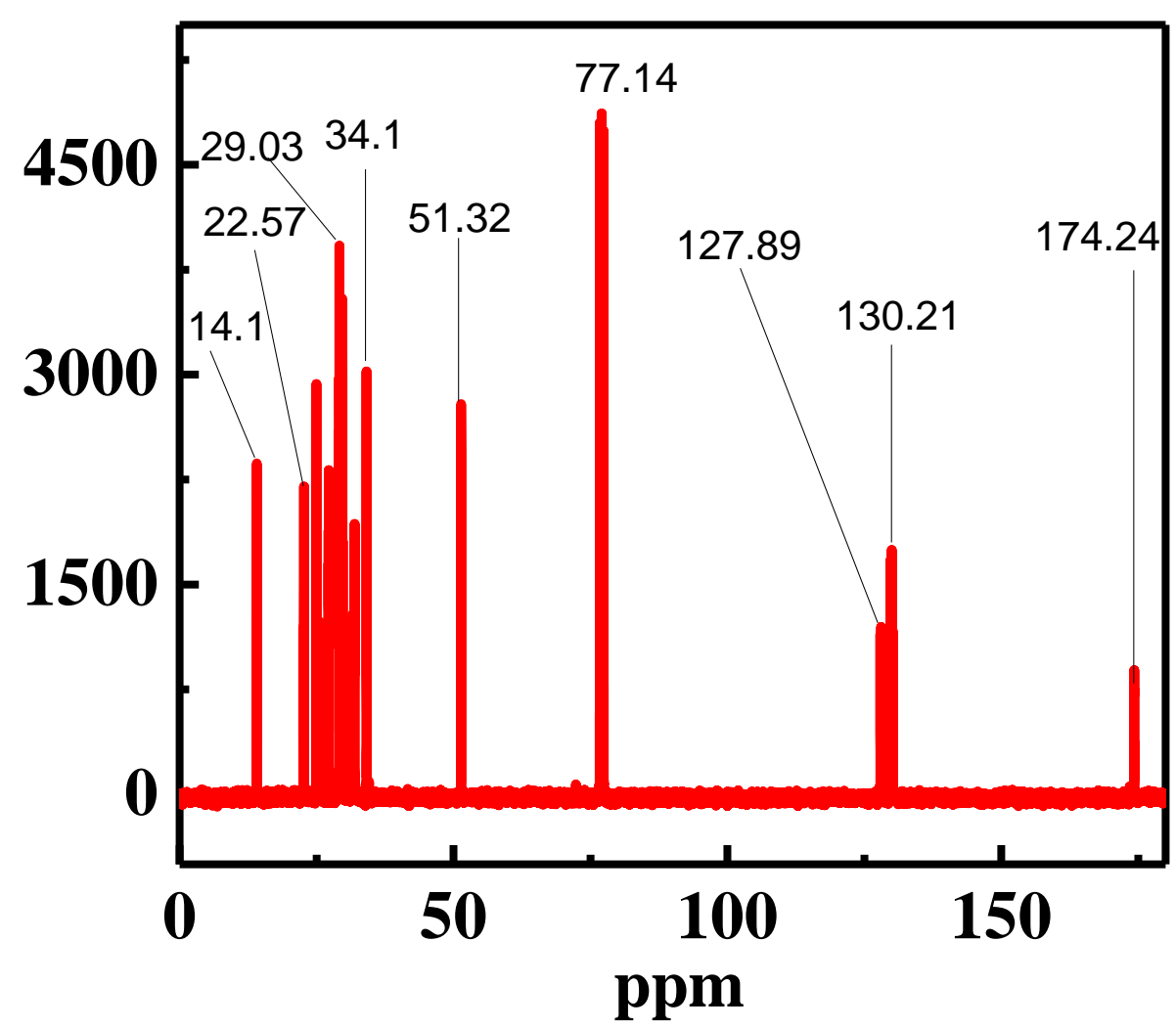

Figure 9. ${ }^{13} \mathrm{C}$ NMR spectrum of RT FAMEs.

\subsection{FT-IR Spectroscopy Analysis}

To identify the various stretching and bending vibration corresponding functional groups and bands of the pure RT seed oil biodiesel sample, the FTIR spectra mid-infrared regions were used. The FT-IR carbonyl group position is highly sensitive to both molecular structure and substituent effects [43]. The two strong characteristic ester absorption bands which are derived from a carbonyl group are $\mathrm{vC}=\mathrm{O}$ at $1750-1730 \mathrm{~cm}^{-1}$ and $\mathrm{C}-\mathrm{O}$ at $1300-1000 \mathrm{~cm}^{-1}$. At 2980-2950, 2950-2850, and 3050-3000 $\mathrm{cm}^{-1}$, respectively, the stretching vibrations of $\mathrm{CH}_{3}, \mathrm{CH}_{2}$, and $\mathrm{CH}$ appear, and at 1475-1350, 1350-1150, and $723\left(\rho \mathrm{CH}_{2}\right) \mathrm{cm}^{-1}$ respectively the bending vibrations of these groups appear [44]. As presented in Figure 10 and Table S5 (Supplementary Materials), at $1743 \mathrm{~cm}^{-1}$, the Rhus typhina seed oil biodiesel methoxy ester carbonyl group has appeared. The peak $3464 \mathrm{~cm}^{-1}$ indicated an overtone of the ester function [45]. The $\mathrm{C}-\mathrm{O}$ stretching vibration exhibited two asymmetric coupling vibrations at $1170 \mathrm{~cm}$ due to O-C-C and $1016 \mathrm{~cm}^{-1}$ due to $v \mathrm{C}-\mathrm{C}(=\mathrm{O})-\mathrm{O}$. The stretching bands of methylene appeared at $2854 \mathrm{~cm}^{-1}$, and methane appeared at 3007, 2925 correspondingly. The bending vibration appeared at 1435 , and $1361 \mathrm{~cm}^{-1}$ belong to the methyl group, and the bending vibration appeared at $723 \mathrm{~cm}^{-1}$ belongs to the methylene group. The peak at $1641 \mathrm{~cm}^{-1}$ shows that $\mathrm{C}=\mathrm{C}$ is not saturated in RT seed oil biodiesel. It is worth noting that the chromatography and spectroscopy techniques can be used to assess biodiesel, making observing, and its superiority. GC-MS, IR, ${ }^{1} \mathrm{H}$ NMR, and ${ }^{13} \mathrm{C}$ NMR was in the FAME-determined features, and different functional group structure is considered to be effective, fast, and easy to use techniques. Therefore, they are used for precise facts elucidation in biodiesel is sensible and dependable. 


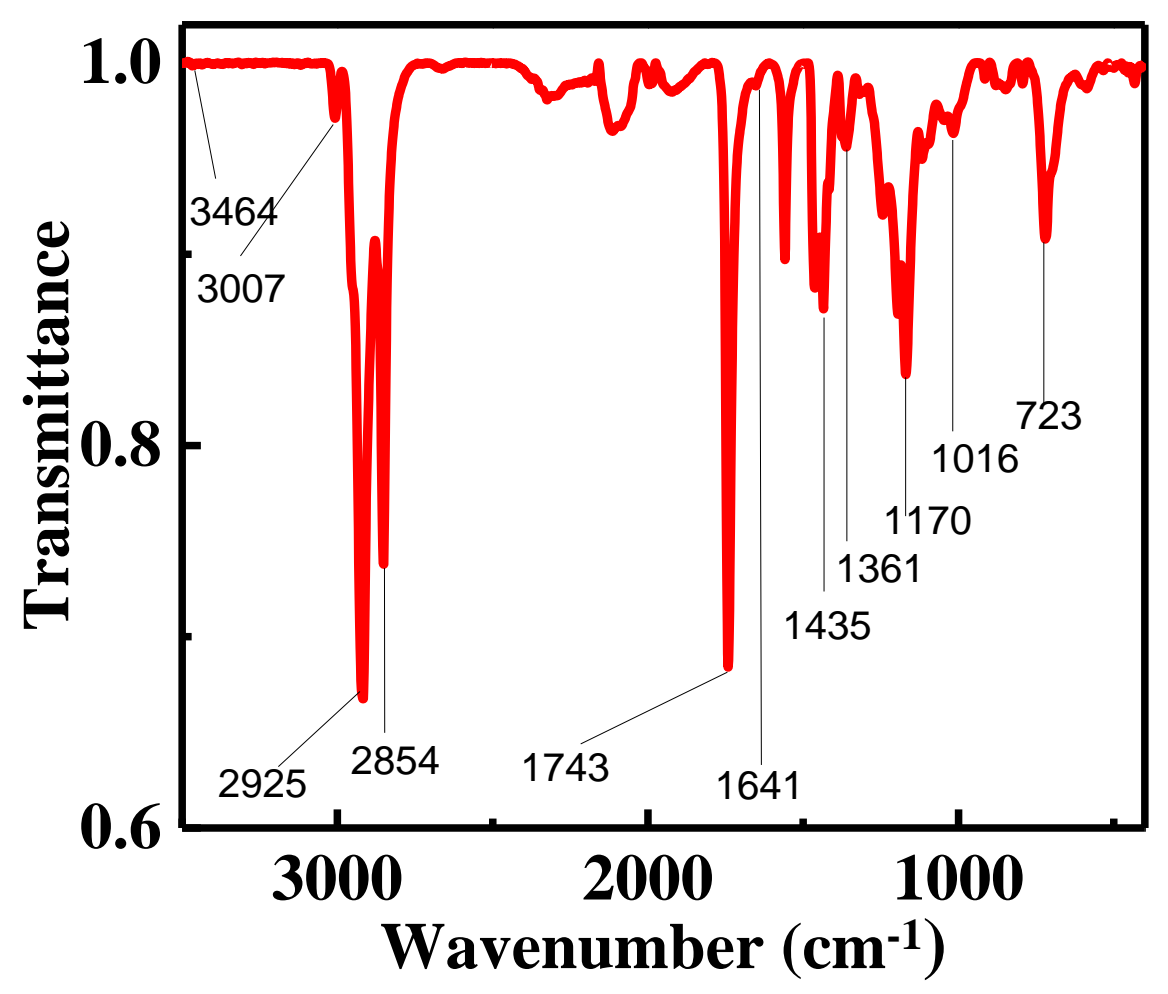

Figure 10. FTIR spectrum of RTME (FAMEs) functional groups.

\subsection{Profiling of R. typhina Oil Fatty Acid Methyl Esters Using GC-MS Analysis}

For the analysis of biodiesel, the most widely used method is gas chromatography. Generally, it is the perfect method to enumerate the trace components configuration accurately. In the present research work, to evaluate the particular methyl ester conversion of prepared RT seed oil to biodiesel, we have applied the gas chromatography and mass spectroscopy. The data on the GC-MS spectrum was shown in Figure 11. We used the GC spectrum and reported seven major peaks, which is consistent with the literature [46]. By using library matching software (NO. NIST 14), the peak was identified, and every peak matched with a fatty acid methyl ester. The retention time of the identified FAMEs and its position are presented in Table 4 . Though by retention time data, the properties of fatty acid methyl ester were prepared and verified by mass spectrometry, and from EI ion source, the mass spectra were obtained [47]. The experimental results were compared and matched with the reported results of the RT seed oil biodiesel. 


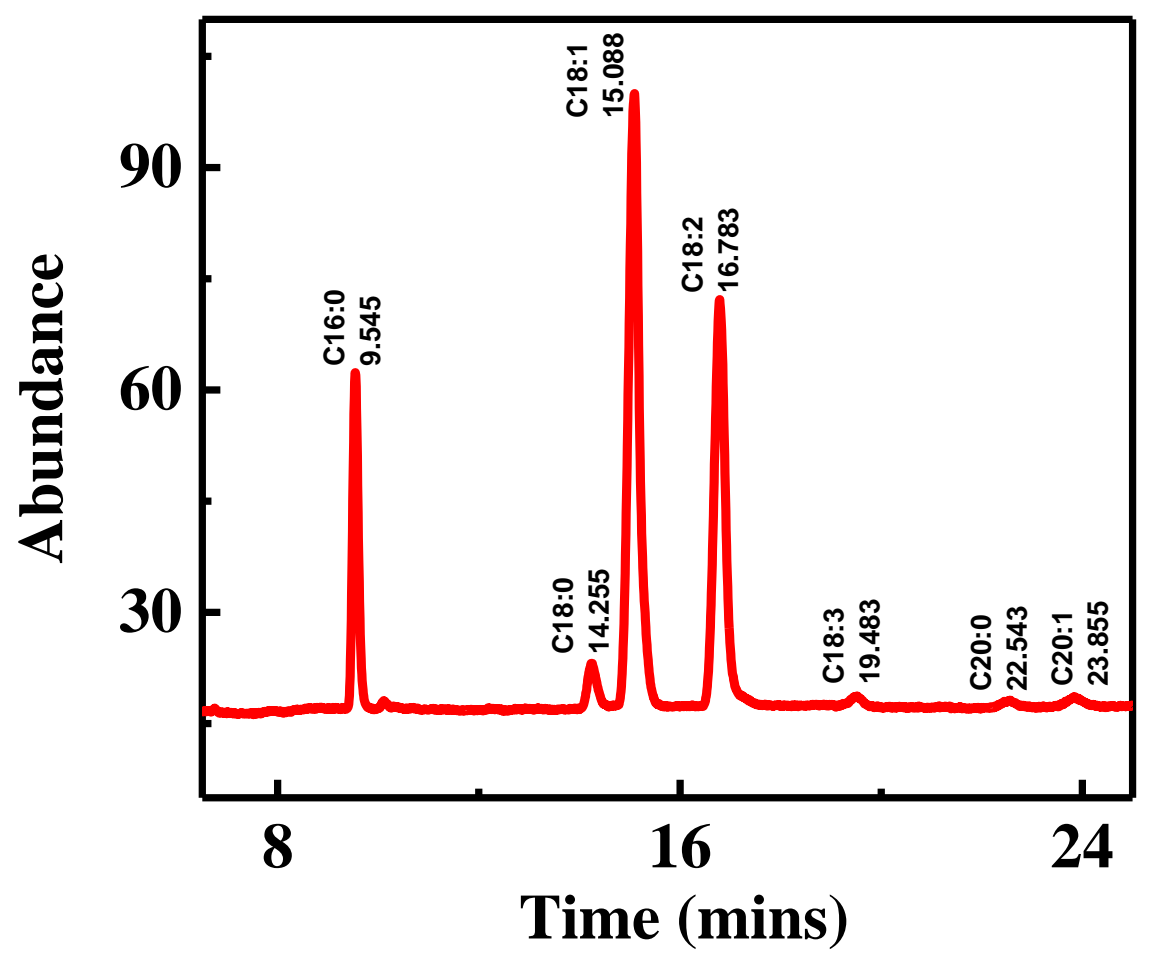

Figure 11. GC-MS analysis of fatty acid compositions of RT seed oil Biodiesel. 
Table 4. The detail fatty acid composition of RT seed oil Biodiesel.

\begin{tabular}{|c|c|c|c|c|c|c|c|c|c|}
\hline S/No & $\begin{array}{l}\text { Fatty Acids/Exp. } \\
\text { Results }\end{array}$ & $\begin{array}{l}\text { Retention } \\
\text { Time }\end{array}$ & $\begin{array}{l}\text { Number of Carbons } \\
\text { and Double Bonds }\end{array}$ & Chemical Name & Chemical Structure & $\begin{array}{c}\text { Weight Percentage } \\
(\%)\end{array}$ & $\begin{array}{c}\text { Molecular } \\
\text { Weight }\end{array}$ & $\begin{array}{l}\text { ZHANG et al., } \\
2018 \text { [21] }\end{array}$ & $\begin{array}{l}\text { Ruan et al., } \\
2012 \text { [20] }\end{array}$ \\
\hline 1 & Palmitic acid & 9.545 & C16:0 & $\begin{array}{l}\text { Hexadecanoic acid, } \\
\text { methyl ester }\end{array}$ & & 14.0 & 270 & $\begin{array}{l}\text { Methyl palmitate } \\
\text { C16:0 }\end{array}$ & $\begin{array}{l}\text { Palmitic acid } \\
\quad \text { C16:0 }\end{array}$ \\
\hline 2 & Stearic acid & 14.248 & C18:0 & methyl stearate & & 3.2 & 298 & $\begin{array}{l}\text { Methyl stearate } \\
\text { C18:0 }\end{array}$ & $\begin{array}{l}\text { Stearic acid } \\
\quad \text { C18:0 }\end{array}$ \\
\hline 3 & Oleic acid & 15.042 & C18:1 & $\begin{array}{l}\text { 9-Octadecenoic acid } \\
\text { (Z)-, methyl ester }\end{array}$ & & 47.2 & 296 & $\begin{array}{l}\text { Methyl oleate } \\
\text { C18:1 }\end{array}$ & $\begin{array}{l}\text { Oleic acid } \\
\text { C18:1 }\end{array}$ \\
\hline 4 & Linoleic acid & 16.797 & C18:2 & $\begin{array}{c}9, \\
\text { 12-Octadecadienoic } \\
\text { acid (Z, Z)-, methyl } \\
\text { ester }\end{array}$ & & 32.2 & 294 & $\begin{array}{l}\text { Methyl linoleate } \\
\text { C18:2 }\end{array}$ & $\begin{array}{l}\text { Linoleic acid } \\
\quad \text { C18:2 }\end{array}$ \\
\hline 5 & $\alpha$-Linolenic acid & 19.565 & C18:3 & $\alpha$-Linolenic acid & & 1.1 & 292 & - & - \\
\hline 6 & Arachidic acid & 22.587 & C20:0 & $\begin{array}{l}\text { Eicosanoic acid, } \\
\text { methyl ester }\end{array}$ & & 0.8 & 326 & - & $\begin{array}{l}\text { Arachidic acid } \\
\quad \text { C20:0 }\end{array}$ \\
\hline 7 & Gondoic acid & 23.922 & C20:1 & $\begin{array}{l}\text { CiS-11- Eicosenoic } \\
\text { acid, methyl ester }\end{array}$ & & 0.5 & 324 & - & $\begin{array}{c}\text { Arachidonic } \\
\text { acid } \\
\text { C20:1 }\end{array}$ \\
\hline
\end{tabular}




\subsection{ICP-OES and EA Analysis}

The occurrence of elements within the biodiesel is offensive, as these elements cause many complications such as stimulating biodiesel deprivation, deterioration of engine, operability complications [48]. The essentials whose capacity in biodiesel requires to be controlled are sodium $(\mathrm{Na})$ and potassium $(\mathrm{K})$, which come from the mechanism in biodiesel manufacture. The amount of metal phosphorus $(\mathrm{P})$ is also significant that originate from the raw materials. The elemental concentrations in RT oil biodiesel (RTOBD) were matched with Petro-diesel. It is confirmed from the results that the concentrations of elements were reasonably lower in RT seed oil biodiesel than high-speed diesel (HSD).

Prerequisites (Elements) such as potassium $(\mathrm{K})$, sodium $(\mathrm{Na})$, magnesium $(\mathrm{Mg})$, and calcium $(\mathrm{Ca})$ within biodiesel guide to the injector, stimulate drain, piston and circle wear, locomotive deposit and pass through a filter plug [49]. The recorded concentrations of $\mathrm{C}, \mathrm{H}, \mathrm{N}$, and $\mathrm{O}$ were mentioned in Table 5 and Figure S3 (Supplementary Materials). The high oxygen content results in a low calorific value in the pyrolysis liquid product. The presence of oxygen reduces the ignition delay time, improves the combustibility and burning degree, thereby reducing CO, PM, and other exhaust emissions. Many researchers [50-52] found that high oxygen content in biodiesel can effectively reduce PM emissions from diesel engines. Table 5 shows that the oxygen content of BD100 is $11.12 \%$. The most common biodiesel has an oxygen content of about 10\% [53-55]. The high hydrogen contents (13.02\%) of biodiesel are attractive for its utilization as fuel [56]. High $\mathrm{H}$ to $\mathrm{C}$ ratio means higher hydrogen molecules in the fuel. As hydrogen has the highest burning velocity between all fuels, whether gases or liquids. Increasing hydrogen ration in the fuel combination means that the fuel-burning velocity will be better and cleaner. The heating value generally increases as the proportion of $\mathrm{H}$ to carbon atoms increases due to the higher heating value of hydrogen than carbon. The HHV is an important property to define the energy content and efficiency of fuels. The HHV of biodiesel $(23.73 \mathrm{MJ} / \mathrm{kg})$ was lower than that of diesel $(49.65 \mathrm{MJ} / \mathrm{kg})$. The structural oxygen content of fuel improves its combustion efficiency due to an increase in the homogeneity of oxygen with the fuel during combustion. We compared with some reported results (Table 5), our experimental results matched them well. The nitrogen content is moderate. Though $\mathrm{K}, \mathrm{Na}, \mathrm{Mg}$, and Ca Values Table S6 (Supplementary Materials) RTOBD (3.219, $70.29,32.74,7.360 \mu \mathrm{g} / \mathrm{g}$ ) were low as compared to $\operatorname{HSD}(213.3,868.3,35.6$, and $21.4 \mu \mathrm{g} / \mathrm{g})$. The highest acceptable concentration of $\mathrm{Na}$ and $\mathrm{K}$ in biodiesel was $5 \mathrm{mg} \cdot \mathrm{kg}^{-1}$, while $\mathrm{P}$ is $10 \mathrm{mg} \cdot \mathrm{kg}^{-1}$ [57], Figure 12 . The concentration of $\mathrm{Na}$ and $\mathrm{K}$ was lower in RTOBD, but in HSD, its amount is very high; that's why RT biodiesel will be more capable of utilizing and environmental friendly.

Table 5. RTBD EA (Elemental Analyser) analysis in comparison with other plant seed and shells biodiesel.

\begin{tabular}{ccccccc}
\hline $\begin{array}{c}\text { Ultimate } \\
\text { Analysis }\end{array}$ & RT-BD & $\begin{array}{c}\text { Pistachio } \\
\text { Shell [58] }\end{array}$ & $\begin{array}{c}\text { Peach } \\
\text { Stones [59] }\end{array}$ & $\begin{array}{c}\text { Apricot } \\
\text { Kernel } \\
\text { Shells [60] }\end{array}$ & $\begin{array}{c}\text { Cherry } \\
\text { Stones [61] }\end{array}$ & $\begin{array}{c}\text { Mahua Seed } \\
\text { [62] }\end{array}$ \\
\hline $\mathrm{C} \%$ & 74.89 & 42.41 & 45.92 & 47.33 & 52.48 & 61.24 \\
$\mathrm{H} \%$ & 13.02 & 5.64 & 6.09 & 6.37 & 7.58 & 8.40 \\
$\mathrm{~N} \%$ & 1.97 & 0.070 & 0.580 & 0.370 & 4.54 & 4.12 \\
$\mathrm{O} \%$ & 10.12 & 51.87 & 47.38 & 45.93 & 35.30 & 25.50 \\
$\mathrm{HHV}$ & 23.73 & 22.21 & 24.07 & 24.29 & 24.11 & 25.30 \\
$(\mathrm{MJ} / \mathrm{kg})$ & & & & & & \\
\hline
\end{tabular}




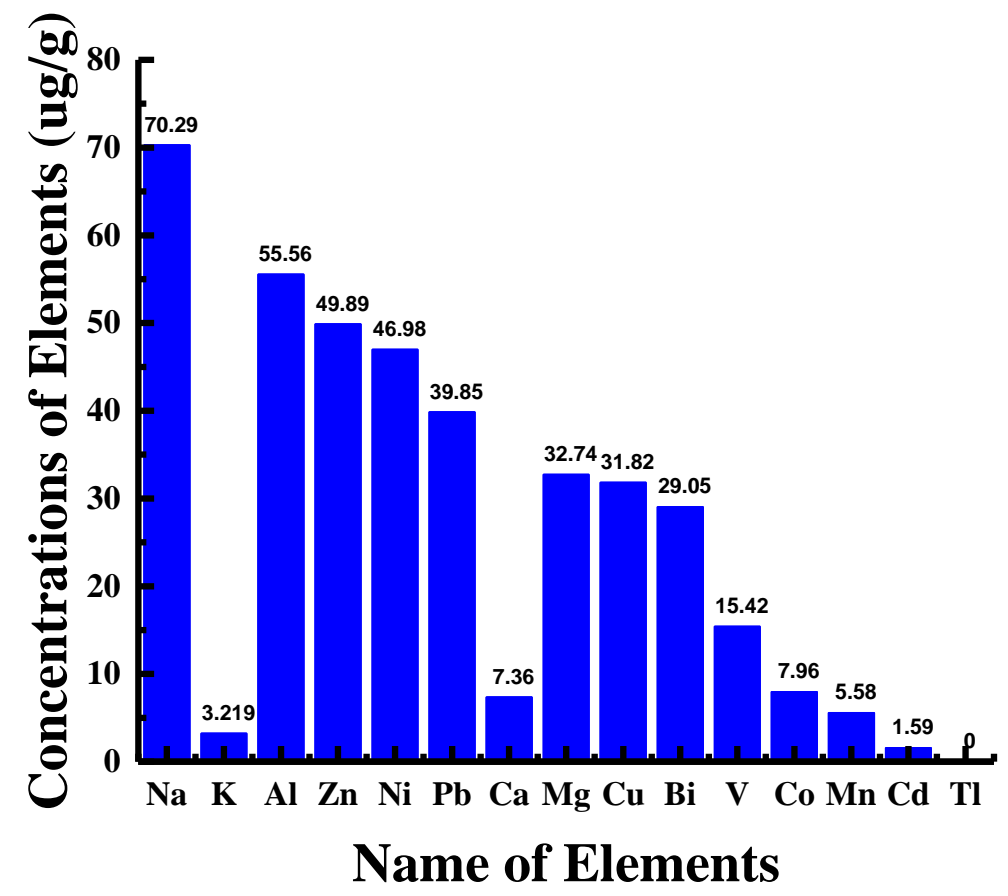

Figure 12. Elemental analysis of RTBD ICP-OES.

\section{Conclusions}

In conclusion, the crude RT seed oil transesterification was done to produce biodiesel with a highest yield of $93.33 \%$ by using a base catalyst. We obtained the optimal transesterification conditions and achieved a maximum oil content of $22 \%$. Seven fatty acids were detected in the RT FAMEs production. ICP-OES and element analyzer indicate it could be environment-friendly energy. RT FAMEs were matched and follow well the recognized biodiesel standards of ASTM D6751 and EN 14214. The RT could be a better choice for renewable energy. This crop can be grown on barren wasteland on a large scale for the mass manufacture of biodiesel to fulfil the energy demand and reduce the energy crises.

Supplementary Materials: The following are available online at http://www.mdpi.com/1996-1073/12/22/4290/s1, Figure S1: R. typhina plant with fruit, Figure S2: (a) RT crude oil filtration (b) optimization (transesterification) (c) BD washing (d) RT biodiesel. Figure S3: RTBD EA (Elemental analysis) for C, H, O, and N, Table S1: Source collection, oil extraction and transesterification of non-edible R. typhina (Sumac fruit) seed oil as biofuel, Table S2: RT FAMEs detail process of optimization, Table S3: 1H NMR spectroscopic data showing the chemical composition of various methyl esters (Methoxy proton) in RT, biodiesel (FAMEs) sample, Table S4: 13C NMR spectroscopic data showing the chemical shift values corresponding to various structural features in RT (Methoxy carbon) FAMEs, Table S5: FTIR data presenting various functional groups in RT FAMEs, Table S6 Comparison ICP-OES elements concentration $(\mathrm{ug} / \mathrm{g})$ of RT-BD with petro-diesel.

Author Contributions: J.C. and Z.Y. supervised the research and revised the manuscript, I.U.K., done the experiment and write the manuscript.

Funding: This work was supported by the National Programs for Nano-Key Project (2018YFB1502100, 2017YFA0206700), the National Natural Science Foundation of China (21835004), 111 Project from the Ministry of Education of China (B12015) and the Fundamental Research Funds for the Central Universities, Nankai University (63191711 and 63191416).

Conflicts of Interest: The authors declare no conflicts of interest.

\section{References}

1. Hoseini, S.S.; Najafi, G.; Ghobadian, B.; Mamat, R.; Ebadi, M.T.; Yusaf, T. Ailanthus altissima (tree of heaven) seed oil: Characterisation and optimisation of ultrasonication-assisted biodiesel production. Fuel 2018, 220, 621-630. [CrossRef] 
2. Ahmad, M.; Zafar, M.; Sadia, H.; Sultana, S.; Arshad, M.; Irfan, M. Physico-chemical characterization of sunflower oil biodiesel by using base-catalyzed transesterification. Int. J. Green Energy 2013. [CrossRef]

3. Živković, S.B.; Veljković, M.V.; Banković-Ilić, I.B.; Krstić, I.M.; Konstantinović, S.S.; Ilić, S.B. Technological, technical, economic, environmental, social, human health risk, toxicological, and policy considerations of biodiesel production and use. Renew. Sustain. Energy Rev. 2017, 79, 222-247. [CrossRef]

4. Bueno, A.V. Performance and emissions characteristics of castor oil biodiesel fuel blends. Appl. Therm. Eng. 2017, 125, 559-566. [CrossRef]

5. Mucak, A. Performance and emission characteristics of a diesel engine fuelled with emulsified biodiesel-diesel fuel blends. Int. J. Autom. Eng. Technol. 2016, 5, 176-185. [CrossRef]

6. Vahid, B.R.; Haghighi, M. Urea-nitrate combustion synthesis of $\mathrm{MgO} / \mathrm{MgAl}_{2} \mathrm{O}_{4}$ nanocatalyst used in biodiesel production from sunflower oil: Influence of fuel ratio on catalytic properties and performance. Energy Convers. Manag. 2016, 126, 362-372. [CrossRef]

7. Gülsen, E.; Olivetti, E.; Freire, F.; Dias, L.; Kirchain, R. Impact of feedstock diversification on the cost-effectiveness of biodiesel. Appl. Energy 2014, 126, 281-296. [CrossRef]

8. Ashraful, A.M. Production and comparison of fuel properties, engine performance, and emission characteristics of biodiesel from various non-edible vegetable oils: A review. Energy Convers. Manag. 2014, 80, 202-228. [CrossRef]

9. Sharma, Y.C.; Singh, B. Development of biodiesel: Current scenario. Renew. Sustain. Energy Rev. 2009, 13, $1646-1651$.

10. Kansedo, J.; Lee, K.T. Process optimization and kinetic study for biodiesel production from non-edible sea mango (Cerbera odollam) oil using response surface methodology. Chem. Eng. J. 2013, 214, 157-164. [CrossRef]

11. Mustafa, B. Potential alternatives to edible oils for biodiesel production-a review of current work. Energy Convers. Manag. 2011, 52, 1479-1492.

12. Rashed, M.M.; Kalam, M.A.; Masjuki, H.H.; Mofijur, M.; Rasul, M.G. Performance and emission characteristics of a diesel engine fueled with palm, jatropha, and moringa oil methyl ester. Ind. Crops Prod. 2016, 79, 70-76. [CrossRef]

13. Fadhil, A.B. Evaluation of apricot (Prunus armeniaca L.) seed kernel as a potential feedstock for the production of liquid biofuels and activated carbons. Energy Convers. Manag. 2017, 133, 307-317. [CrossRef]

14. Sinha, P.; Islam, M.A.; Negi, M.S.; Tripathi, S.B. Changes in oil content and fatty acid composition in Jatropha curcas during seed development. Ind. Crops Prod. 2015, 77, 508-510. [CrossRef]

15. Foidl, N.; Foidl, G.; Sanchez, M.; Mittelbach, M.; Hackel, S. Jatropha Curcas L. as a source for the production of biofuel in Nicaragua. Bioresour. Technol. 1996, 58, 77-82. [CrossRef]

16. Bhatti, H.N.; Hanif, M.A.; Qasim, M.; Ata-ur-Rehman. Biodiesel production from waste tallow. Fuel 2008, 87, 2961-2966. [CrossRef]

17. Fadhil, A.B.; Aziz, A.M.; Altamer, M.H. Biodiesel production from Silybum marianum L. seed oil with high FFA content using sulfonated carbon catalyst for esterification and base catalyst for transesterification. Energy Convers. Manag. 2016, 108, 255-265. [CrossRef]

18. Aldobouni, I.A.; Fadhil, A.B.; Saied, I.K. Optimized alkali - catalyzed transesterification of wild mustard (Brassica juncea L.) seed oil. Energy Sources Part A 2016, 38, 2319-2325. [CrossRef]

19. Chisti, Y. Biodiesel from microalgae. Biotechnol. Adv. 2007, 25, 294-306. [CrossRef] [PubMed]

20. Ruan, C.J.; Xing, W.H.; Jaime, A.; da Silva, T. The potential of five plants growing on unproductive agriculture land as a biodiesel source. Renew. Energy 2012, 41, 191-199. [CrossRef]

21. Zhang, F.; Ren, H.; Tong, G. Production of biodiesel from the extract of the sumac fruit cluster. Cellul. Chem. Technol. 2018, 52, 1275-1279.

22. Kpikpi, W.M. Jatropha curcus as a vegetable source of renewable energy. ANSTI Sub Netw. Meet. Renew. Energy 2002, 13, 18-22.

23. Ahmad, M.; Khan, M.A.; Zafar, M.; Sultana, S. Practical Handbook on Biodiesel Production and Properties; Taylor and Francis: London, UK, 2012; pp. 1-157.

24. Antolin, G.; Tinaut, F.V.; Briceno, Y.; Castano, V.; Perez, C.; Ramrez, A.I. Optimization of biodiesel production by sunflower oil transesterification. Bioresour. Technol. 2002, 83, 111-114. [CrossRef]

25. Bhandari, D.C.; Chandel, K.P.S. Status of rocket germplasm in India: Research accomplishments and priorities. Rocket Mediterr. Crop World 1996, 67, 13-14. 
26. Christie, W.W. Lipid Analysis, 3rd ed.; Oily Press: Bridgwater, UK, 2003.

27. Encinar, J.M.; Gonzalez, J.F.; Rodriguez, R.A. Biodiesel from used frying oil. Variables affecting the yields and characteristics of the biodiesel. Ind. Eng. Chem. Res. 2005, 44, 5491-5499. [CrossRef]

28. Dorado, M.P.; Ballesteros, E.; Lopez, F.J.; Mittelbach, M. Optimization of alkali catalyzed transesterification of Brassica Carinata oil for biodiesel production. Energy Fuels 2004, 18, 77-83. [CrossRef]

29. Leung, D.; Guo, Y. Transesterification of neat and used frying oil: Optimization for biodiesel production. Fuel Process. Technol. 2006, 87, 883-890. [CrossRef]

30. Kafuku, G.; Mbarawa, M. Alkaline catalyzed biodiesel production from Moringa oleifera oil with optimized production parameters. Appl. Energy 2010, 87, 2561-2565. [CrossRef]

31. Rashid, U.; Anwar, F. Production of biodiesel through optimized alkaline-catalyzed transesterification of rapeseed oil. Fuel 2008, 87, 265-273. [CrossRef]

32. Ma, F.; Clements, L.D.; Hanna, M.A. The effect of mixing on transesterification of beef tallow. Bioresour. Technol. 1999, 69, 289-293. [CrossRef]

33. Peterson, C.L.; Reece, D.L.; Cruz, R.; Thompson, J. A comparison of ethyl and methyl esters of vegetable oil as diesel fuel substitutes. In Proceedings of the an Alternative Energy Conference, Nashville, TN, USA, 12-15 December 1992; pp. 99-110.

34. Tomasevic, A.V.; Siler-Marinkovic, S.S. Methanolysis of Used Frying Oil. Fuel Process. Technol. 2003, 82, 1-6. [CrossRef]

35. Eevera, T.; Rajendran, K.; Saradha, S. Biodiesel production process optimization and characterization to assess the suitability of the product for varied environmental conditions. Renew. Energy 2009, 34, 762-765. [CrossRef]

36. Shu, Q.; Gao, J.; Nawaz, Z.; Liao, Y.; Wang, D.; Wang, J. Synthesis of biodiesel from waste vegetable oil with large amounts of free fatty acids using a carbon-based solid acid catalyst. Appl. Energy 2010, 87, 2589-2596. [CrossRef]

37. Mello, V.M.; Oliveira, C.C.; Fraga, G.W.; Nascimento, C.J.D.; Suarez, P.A.Z. Determination of the content of fatty acid methyl esters (FAMEs) in biodiesel samples using 1H NMR spectroscopy. Magn. Reson. Chem. 2008, 46, 1051-1054. [CrossRef] [PubMed]

38. Monterio, M.R.; Ambrozin, A.R.P.; Liao, L.M.; Ferreira, A.G. Determination of biodiesel blends levels in different diesel samples by 1H NMR. Fuel 2009, 88, 691-696. [CrossRef]

39. Samios, D.; Pedrotti, F.; Nicolau, A.; Martini, D.D.; Dalcen, F.M. A transesterification double process-TDSP for biodiesel preparation from fatty acid tryglycerides. Fuel Process. Technol. 2009, 90, 599-605. [CrossRef]

40. Liu, C.; Lv, P.; Yuan, Z.; Yan, F.; Luo, W. Biodiesel from different oil using fixed-bed and flow reactors. Renew. Energy 2010, 35, 1531-1536. [CrossRef]

41. Gelbard, G.; Bres, O.; Vargas, R.M.; Vielfaure, F.; Schuchardt, U.F. 1H nuclear magnetic resonance determination of the yield of the transesterification of rapeseed oil with methanol. Am. Oil Chem. Soc. 1995, 72, 1239-1241. [CrossRef]

42. Knothe, G. Monitoring a progressing transesterification reaction by fiber optic NIR spectroscopy with correlation to 1H NMR spectroscopy. Am. Oil Chem. Soc. 2000, 77, 489-493. [CrossRef]

43. Pasto, D.; Johnson, C.; Miller, M. Experiments and Techniques in Organic Chemistry, 1st ed.; Prentice-Hall: Upper Saddle River, NJ, USA, 1992.

44. Guillen, M.D.; Cabo, N. Infra-red spectroscopy in the study of edible oils and fats. Sci. Food Agric. 1997, 75, 1-11. [CrossRef]

45. Safar, M.; Bertrand, D.; Robert, P.; Devaux, M.D.; Genut, C. Characterization of edible oil, butter, and margarine by Fourier Transfer Infra-Red spectroscopy with attenuated total reflectance. Am. Chem. Soc. 1994, 71, 371-377. [CrossRef]

46. Ahmad, M.; Ullah, K.; Khan, M.A.; Zafar, M.; Tariq, M.; Ali, S. Physico-chemical analysis of hemp oil biodiesel: A promising non-edible new source for bioenergy. Energy Sources Part A 2011, 33, 1365-1374. [CrossRef]

47. Wang, L.; Yu, H. Biodiesel from Siberian apricot (Prunus sibirica L.) seed kernel oil. Bioresour. Technol. 2012, 112, 355-358. [CrossRef] [PubMed]

48. Schober, S.; Mittelbach, M. Influence of diesel particulate filter additives on biodiesel Quality. Eur. J. Lipid Sci. Technol. 2005, 107, 268-271. [CrossRef] 
49. McCormick, R.L.; Alleman, T.L.; Ratcliff, M.; Moens, L.; Lawrence, R. Survey of the Quality and Stability of Biodiesel and Biodiesel Blends in the United States in 2004; National Renewable Energy Laboratory: Golden, CO, USA, 2005.

50. Song, H.; Quinton, K.S.; Peng, Z.; Zhao, H.; Ladommatos, N. Effects of the oxygen content of Fuels on combustion and emissions of diesel engines. Energies 2016, 9, 28. [CrossRef]

51. Nakano, M.; Okawa, K. Study of oxygen-containing hydrocarbons in exhaust emission from a spark ignition combustion engine. Int. J. Eng. Res. 2014, 15, 572-580. [CrossRef]

52. Mwang, J.K.; Lee, W.J.; Chang, Y.C.; Chen, C.Y.; Wang, L.C. An overview: Energy saving and pollution reduction by using green fuel blends in diesel engines. Appl. Energy 2015, 159, 214-236. [CrossRef]

53. Lin, B.F.; Huang, J.H.; Huang, D.Y. Effects of Biodiesel from Palm Kernel oil on the engine performance, Exhaust emissions and combustion characteristics of a direct injection diesel engine. Energy Fuels 2008, 22, 4229-4234. [CrossRef]

54. Singh, D.; Subramanian, K.A.; Juneja, M.; Singh, K.; Singh, S. Investigating the effect of fuel cetane number, oxygen content, fuel density, and engine operating variables on NOx emissions of a heavy-duty diesel engine. Environ. Prog. Sustain. Energy 2017, 36, 214-221. [CrossRef]

55. Demirbas, A. Combustion efficiency impacts of biofuels. Energy Sources Part A 2009, 31, 602-609. [CrossRef]

56. Huber, G.W.; Iborra, S.; Corma, A. Synthesis of transportation fuels from biomass: Chemistry, catalysts, and engineering. Chem. Rev. 2006, 106, 4044-4098. [CrossRef] [PubMed]

57. Korn, M.G.A.; Santos, D.S.S.; Welz, B.; Vale, M.G.R.; Teixeira, A.P.; Lima, D.D.C.; Ferreira, S.L.C. Atomic spectrometric methods for the determination of metals and metalloids in automotive fuels. A Review. Talanta 2007, 73, 1-11. [CrossRef] [PubMed]

58. Acıkalın, K.; Karaca, F.; Bolat, E. Pyrolysis of pistachio shell: Effects of pyrolysis conditions and analysis of products. Fuel 2012, 95, 169-177. [CrossRef]

59. Uysal, T.; Duman, G.; Onal, Y.; Yasa, I.; Yanik, J. Production of activated carbon and fungicidal oil from peach stone by a two-stage process. J. Anal. Appl. Pyrolysis 2014, 108, 47-55. [CrossRef]

60. Demiral, I.; Kul, S.C. Pyrolysis of apricot kernel shell in a fixed-bed reactor: Characterization of bio-oil and char. J. Anal. Appl. Pyrolysis 2014, 107, 17-24. [CrossRef]

61. Duman, G.; Okutucu, C.; Ucar, S.; Stah, R.; Yanik, J. The slow and fast pyrolysis of cherry seed. Bioresour. Technol. 2011, 102, 1869-1878. [CrossRef] [PubMed]

62. Pradhan, D.; Singh, R.K.; Bendu, H.; Mund, R. Pyrolysis of Mahua seed (Madhuca indica) production of biofuel and its characterization. Energy Convers. Manag. 2016, 108, 529-538. [CrossRef] 